\title{
Jurist-Diction
}

Volume 3 No. 5, September 2020

\section{Perlindungan Hukum Bagi Konsumen Atas Perjanjian Jual Beli Rumah Dengan Mekanisme Perjanjian Pengikatan Jual Beli (PT. Berkat Jaya Land)}

\author{
Febriyanti Putri AR. \\ fbrfbg@ymail.com \\ Universitas Airlangga
}

\begin{abstract}
How to cite:
Febriyanti Putri AR.,

'Perlindungan Hukum Bagi

Konsumen Atas Perjanjian

Jual Beli Rumah Dengan

Mekanisme Perjanjian

Pengikatan Jual Beli (PT.

Berkat Jaya Land)' (2020) Vol.

3 No. 5 Jurist-Diction.

Histori artikel:

Submit 22 Juli 2020;

Diterima 14 Agustus 2020;

Diterbitkan 1 September 2020.

DOI:

10.20473/jd.v3i5.21976
\end{abstract}

\begin{abstract}
Abstrak
Artikel ini berjudul Perlindungan Hukum bagi Konsumen atas Perjanjian Jual Beli dengan Mekanisme Perjanjian Pengikatan Jual Beli (Studi Kasus PT. Berkat Jaya Land). Rumusan masalah dari penelitian ini yang pertama bentuk perlindungan hukum atas jual beli rumah melalui mekanisme Perjanjian Pengikatan Jual Beli, yang kedua merupakan upaya hukum atas penyelesaian sengketa jual beli rumah melalui mekanisme Perjanjian Pengikatan Jual Beli. Metode yang digunakan merupakan metode penelitian normatif yaitu proses penelitian hukum dengan cara menemukan aturan hukum, prinsip-prinsip hukum, maupun doktrin-doktrin hukum. Hasil penelitian menunjukkan bahwa Perjanjian Pengikatan Jual Beli yang para pihak buat dalam perkara Putusan No: 09/BPSK-SBY/Put-Arbitrase/II/2019 dan Putusan No. 33/Pdt.G/2019/ PN Gresik mengikat para pihaknya sehingga para pihak sepatutnya untuk dilindungi hak-haknya diantaranya membuat aturan yang dapat menjamin hak-hak konsumen di dalamnya serta menegakkan peraturan tersebut berdasarkan hukum administrasi, hukum pidana, hukum perdata. Kemudian upaya hukum yang dapat digunakan para pihak dalam pokok perkara Putusan No. 33/Pdt.G/2019/PN Gresik melalui pengadilan dengan Class Action agar lebih efisien dan efektif dengan cara mengajukan somasi atau bila belum menemukan titik terang dapat dilakukan pembatalan perjanjian, tuntutan ganti rugi hingga melaksanakan atau pembatalan perjanjian beserta ganti rugi. Sedangkan pokok perkara Putusan No: 09/BPSK-SBY/Put-Arbitrase/ II/2019 dalam melakukan gugatannya melalui luar pengadilan yaitu Badan Penyelesaian Sengketa Konsumen (BPSK) dengan cara arbitrase berpatokan pada Pasal 19 Undang-Undang Nomor 8 Tahun 1999 tentang Perlindungan Konsumen berdasarkan pilihan bentuk penggantian kerugian bergantung pada kerugian yang sungguh-sungguh diderita oleh konsumen dan disesuaikan dengan hubungan hukum yang ada diantara mereka.
\end{abstract}

Kata Kunci: Perlindungan Hukum; Perjanjian Pengikatan Jual Beli.

\section{Pendahuluan}

Rumah adalah "bangunan gedung yang berfungsi sebagai tempat tinggal yang layak huni, sarana pembinaan keluarga, cerminan harkat dan martabat penghuninya, serta aset bagi pemiliknya". artinya rumah menurut Pasal 1 ayat (7) Undang- 
Undang Nomor 1 Tahun 2011 tentang Perumahan dan Pemukiman merupakan kebutuhan dasar manusia untuk meningkatkan kesejahteraan serta mempertahankan kelangsungan hidupnya.

Ada beberapa cara yang dapat ditempuh orang atau badan hukum untuk memiliki rumah: ${ }^{1}$

a. Membangun rumah diatas tanah haknya sendiri;

b. Membeli rumah milik orang lain;

c. Mendapatkan hibah rumah dari orang lain;

d. Melakukan tukar menukar rumah;

e. Memenangkan lelang rumah; dan

f. Mendapatkan warisan rumah.

Misalnya Perusahaan Pembangunan Perumahan atau Developer yang merupakan pelaku usaha berbentuk badan hukum dalam menyelenggarakan pembangunanan rumah dengan membangun rumah diatas tanah haknya sendiri dengan bersertipikat Hak Guna Bangunan (HGB) atau sertipikat Hak Pakai yang di jual kembali kepada calon pembeli. Developer merupakan "suatu perusahaan yang berusaha dalam bidang pembangunan perumahan dari berbagai jenis dalam jumlah yang besar di atas suatu areal tanah yang akan merupakan suatu kesatuan lingkungan pemukiman yang dilengkapi dengan prasarana-prasarana lingkungan dan fasilitas-fasilitas sosial yang diperlukan oleh masyarakat penghuninya”. keterangan ini dijelaskan dalam Pasal 5 ayat (1) Peraturan Menteri Nomor 5 Tahun 1974 tentang Ketentuan-Ketentuan Mengenai Penyediaan Dan Pemberian Tanah Untuk Keperluan Perusahaan.

Setelah krisis moneter sebagian besar minat para calon pembeli adalah mencari rumah yang siap huni, harga terjangkau, dan lokasi strategis membuat para developer sebagai pelaku usaha di bidang perumahan memanfaatkan kesempatan ini sehingga kedudukan para pengembang lebih unggul dan berhasil menguasai dunia perdagangan di bidang perumahan. Pada prakteknya karena masih banyak pengembang menawarkan rumah yang belum siap untuk dihuni bahkan belum dibangun atau masih tahap perencanaan sehingga dalam Pasal 42 Undang-Undang

\footnotetext{
1 Urip Santoso, Hukum Perumahan (Kencana 2016).[213].
} 
No. 1 Tahun 2011 tentang Perumahan dan Pemukiman diaturlah ketentuan jika pengembang ingin memasarkan rumah yang belum siap huni harus melalui mekanisme Perjanjian Pengikatan Jual Beli (PPJB).

Perjanjian Pendahuluan Jual Beli atau Perjanjian Pengikatan Jual Beli (PPJB) dalam penjelasan Undang-Undang No. 1 Tahun 2011 tentang Perumahan dan Pemukiman Pasal 42 ayat (1) adalah "kesepakatan melakukan jual beli rumah yang masih dalam proses pembangunan antara calon pembeli rumah dengan penyedia rumah yang diketahui oleh pejabat yang berwenang." Ketentuan Perjanjian Pengikatan Jual Beli (PPJB) tersebut diatur secara khusus dalam Peraturan Menteri Pekerjaan Umum Dan Perumahan Rakyat Republik Indonesia Nomor 11/Prt/M/2019 Tentang Sistem Perjanjian Pendahuluan Jual Beli Rumah. Tujuan diaturnya Perjanjian Pengikatan Jual Beli karena perjanjian ini berasaskan kebebasan berkontrak yang artinya terdapat kebebasan dalam menentukan isi perjanjian sesuai kesepakatan antara pelaku usaha dengan pembeli serta merupakan perjanjian timbal balik sebab para pihaknya memiliki kewajiban yang saling berhadapan satu sama lain serta harus dipenuhi yaitu penjual memperoleh pembayaran atas penjualan objek perikatan dan pembeli memperoleh objek perikatan tersebut sehingga timbul rasa percaya dan memberi rasa aman.

Dalam Hukum Perdata, dikenal yang namanya perjanjian. Perjanjian merupakan perbuatan dengan mana satu orang atau lebih mengikatkan dirinya terhadap satu orang lain atau lebih, artinya Perjanjian Pengikatan Jual Beli merupakan perjanjian yang lahir dari suatu perbuatan hukum yaitu Jual Beli Rumah yang ditujukan agar mengikat antara pembeli dan penjual yang akibatnya diatur oleh hukum dan akibat tersebut dikehendaki oleh para pihak atas dasar sepakat. Jual Beli dalam Pasal 1457 BW (Burgerlijk Wetboek) adalah "suatu perjanjian bertimbal balik, dimana pihak penjual berjanji untuk menyerahkan hak milik atas suatu barang dan pihak pembeli berjanji untuk membayar sejumlah uang sebagai imbalan”.

Penyelenggaraan pembangunan perumahan merupakan jual beli hak atas tanah yang diatasnya didirikan bangunan rumah antara penyelenggara pembangunan rumah dan pembeli. Bentuk peralihan hak atas tanah dalam Jual 
Beli adalah Dialihkan, artinya berpindahnya hak atas tanah dari pemegang haknya kepada pihak lain karena suatu perbuatan hukum yang sengaja dilakukan dengan tujuan agar pihak lain memperoleh hak atas tanah tersebut. Dalam dialihkannya pihak yang mengalihkan hak tersebut berhak dan berwenang untuk mengalihkan hak atas tanah sedangkan pihak yang memperoleh hak atas tanah adalah orang yang memenuhi syarat sebagai subjek hak atas tanah yang menjadi objek pemindahan hak. ${ }^{2}$ Namun dalam pembentukan Perjanjian Pengikatan Jual Beli tidak sematamata menyebabkan beralihnya hak atas tanah dari pelaku usaha kepada pembeli karena belum ada penyerahan bagunan rumah.

Kedudukan pembeli atau konsumen yang masih lemah menyebabkan pelaku usaha menyalah gunakan kesempatan tersebut, seperti gencarnya penjualan rumah dengan mekanisme Perjanjian Pengikatan Jual Beli yang masih sering melanggar hak-hak konsumen yang ada dalam Undang-Undang Nomor 8 Tahun 1999 tentang Perlindungan Konsumen sehingga membuat kedudukan pelaku usaha yang lebih kuat dan unggul daripada konsumen. Hal ini harus diperhatikan dan dilindungi oleh Pemerintah karena sejatinya kedudukan pelaku usaha dan konsumen sama dimata hukum.

Hal ini terjadi antara PT. Berkat Jaya Land dan Christian Wijaya pada Putusan No: 09/BPSK-SBY/Put-Arbitrase/II/2019. PT. Berkat Jaya Land (Tergugat) merupakan perusahaan yang bergerak dalam bidang pembangunan perumahan sedangkan Christian Wijaya (Penguggat) merupakan salah satu konsumen dari sekian banyak konsumen yang membeli rumah berlokasi di perumahan Royal City, Kabupaten Gresik, Jawa Timur.

Agar lahir suatu hubungan hukum antara Tergugat dan Penggugat, mereka sepakat dan saling mengikatkan diri melalui Perjanjian Pengikatan Jual Beli (PPJB). Dalam Perjanjian tersebut, terurai hak dan kewajiban apa saja yang harus dilaksanakan antara pembeli dan penjual. Penggugat yang telah membayar lunas rumah tersebut, berbanding terbalik dengan Tergugat. Ia tidak melaksanakan

\footnotetext{
2 ibid.[217].
} 
kewajibannya sebagaimana yang diatur dalam perjanjian tersebut. Tergugat harusnya melakukan serah terima rumah dengan luas 90 beserta sertifikat kepemilikannya pada tanggal 27 Februari 2018, namun hingga saat ini tidak ada keterangan yang jelas mengenai kepastian rumah tersebut dengan alasan tanah yang akan dibangun rumah milik Penggugat dijadikan sebagai agunan Bank.

Oleh karena merasa dirugikan, Penggugat mengajukan gugatannya ke Badan Penyelesaian Sengketa Konsumen (BPSK). Sidang yang dilakukan hingga 3 (tiga) kali tersebut belum menemukan titik terang serta itikad baik dari Tergugat untuk menyelesaikan permasalahan tersebut. Sama halnya dengan kasus diatas, pada Putusan No. 33/Pdt.G/2019/PN Gresik menyatakan bahwasannya delapan penggugat lainnya yang merupakan konsumen dari perumahan Royal City tersebut juga merasa dirugikan. Belum diserah terimakannya rumah yang telah dijanjikan oleh Tergugat membuat mereka melakukan Class Action dengan meggugat ke Pengadilan Negeri Gresik. Namun Class Action yang mereka lakukan belum juga menemukan titik terang dan kepastian yang jelas dari Tergugat.

Asas kebebasan berkontrak serta asas itikad baik yang mendasari Perjanjian Pengikatan Jual Beli tersebut seperti dikesampingkan oleh Tergugat. Perlindungan konsumen dalam era pasar global menjadi sangat penting karena di samping konsumen mempunyai hak-hak yang bersifat universal juga mempunyai hak-hak yang bersifat sangat spesifik (baik situasi maupun kondisi). ${ }^{3}$ Definisi Perlindungan konsumen dalam Undang-Undang Nomor 8 Tahun 1999 tentang Perlindungan Konsumen Pasal 1 ayat (1) adalah "segala upaya yang menjamin adanya kepastian hukum untuk memberi perlindungan kepada konsumen.

Tujuan dibentuknya dijelaskan dalam Pasal 3 Undang-Undang Nomor 8 Tahun 1999 tentang Perlindungan Konsumen, antara lain:

a. Menjaga kepentingan umum dan meningkatkan efisiensi ekonomi nasional sebagai salah satu upaya untuk meningkatkan kesejahteraan rakyat;

b. Mewujudkan iklim usaha yang kondusif melalui pengaturan persaingan usaha yang sehat sehingga menjamin adanya kepastian kesempatan berusaha yang

${ }^{3}$ Celina Tri Siwi Kristihanti, Hukum Perlindungan Konsumen (Sinar Grafika 2018).[6]. 
sama bagi pelaku usaha besar, pelaku usaha menengah, dan pelaku usaha kecil; c. Mencegah praktek monopoli dan atau persaingan usaha tidak sehat yang ditimbulkan oleh pelaku usaha; dan

d. Terciptanya efektivitas dan efisiensi dalam kegiatan usaha.

Pentingnya pemberian informasi yang jelas bagi konsumen bukanlah tugas dari pelaku usaha semata-mata, melainkan juga tugas dari konsumen untuk mencapai apa dan bagaimana informasi yang dianggap relevan yang dapat dipergunakan untuk membuat suatu keputusan tentang penggunaan, pemanfaatan maupun pemakaian barang dan/atau jasa tertentu. ${ }^{4}$ Untuk itu, pendidikan "perlindungan konsumen" menjadi suatu hal yang signifikan, tidak hanya untuk memberikan bargaining position yang lebih kuat pada konsumen untuk menegakkan hak-haknya, melainkan juga agar dapat tercipta aturan main yang lebih fair bagi semua pihak. ${ }^{5}$

Berdasarkan latar belakang yang diuraikan diatas maka dapat dirumuskan permasalahan sebagai berikut bentuk perlindungan hukum atas jual beli rumah dengan mekanisme Perjanjian Pengikatan Jual Beli dan upaya hukum atas penyelesaian sengketa jual beli rumah dengan mekanisme Perjanjian Pengikatan Jual Beli.

\section{Bentuk Perlindungan Hukum atas Jual Beli Rumah dengan Mekanisme Perjanjian Pengikatan Jual Beli}

Perjanjian Pengikatan Jual Beli (PPJB) adalah kesepakatan melakukan jual beli rumah yang masih dalam proses pembangunan antara calon pembeli rumah dan penyedia rumah yang diketahui oleh pejabat yang berwenang. Perjanjian tersebut dimaksudkan agar para pihak yang terdiri dari penjual dan pembeli melakukan kesepakatan yang dapat melahirkan hak dan kewajiban atau yang biasa disebut hubungan hukum. Pentingnya untuk mengetahui hakikat hubungan hukum ini agar apabila salah satu pihak tidak dapat memenuhi kewajibannya dalam suatu hubungan tersebut maka pihak yang lain dapat menegakkan haknya dan pihak yang dilanggar

4 Gunawan Widjaja dan Ahmad yani, Hukum tentang Perlindungan Konsumen (Gramedia Pustaka 2000).[3-4].

5 ibid. 
haknya dapat mengajukan gugatan ke pengadilan untuk menegakkan keadilan atas pemenuhan hak dan kewajiban tersebut.

Seperti contoh pokok perkara Putusan No: 09/BPSK-SBY/Put-Arbitrase/ II/2019 dan Putusan No. 33/Pdt.G/2019/PN Gresik. Perbuatan hukum yang timbul akibat hubungan hukum kedua belah pihak atas pembelian sebuah rumah merupakan akibat dari Jual Beli. Hak dan kewajiban para pihak yang seharusnya dipenuhi bersinggungan dari apa yang telah di perjanjikan dalam Perjanjian Pengikatan Jual Beli (PPJB) yang merupakan peraturan perundang-undangan bagi mereka yang membuatnya artinya para pihak harus tunduk atas aturan tersebut. Kenyataannya PT. Berkat Jaya Land tidak melaksanakan kewajibannya yang seharusnya menyelesaikan pembangunan rumah berserta infrastrukturnya kemudian dilakukannya serah terima atas rumah beserta sertifikatnya seluas tersebut 24 bulan 7 hari (tepatnya 27 Februari 2018). Setelah disepakatinya Perjanjian Jual Beli tersebut dengan alasan bahwa tanah tersebut dijadikan sebagai agunan Bank Swasta Indonesia menyebabkan pembangunan rumah tipe Praha tersebut tertunda hingga saat ini.

Christian Wijaya yang telah melaksanakan kewajibannya sebagai pembeli dengan membayar lunas (Cash Keras) rumah tersebut belum memperoleh haknya serta tidak ada kepastian dan keterangan terkait rumah dari PT. Berkat Jaya Land setelah mengajukan somasi pertama pada tanggal 22 Januari 2019, pada akhirnya Christian Wijaya mengajukan gugatannya ke Badan Penyelesaian Sengketa Konsumen (BPSK). Pada tanggal 4 Februari 2019 dengan membawa beberapa bukti, Christian Wijaya mengajukan pengaduan kronologi atas wanprestasi tersebut ke BPSK. Sidang sengketa pertama yang dilakukan dengan cara Arbitrase pada tanggal 27 Februari 2019 dihadiri oleh Christian Wijaya selaku Penggugat, namun pelaku usaha selaku Tergugat tidak hadir dan diminta hadir pada sidang selanjutnya. Pada tanggal 6 Maret 2019, sidang selanjutnya dilakukan namun sama dengan sidang pertama, Tergugat tidak hadir. Kemudian sidang putusan pada tanggal 13 Maret 2019, Penggugat serta Tergugat yang hanya diwakilkan oleh pengacaranya hadir untuk mendengar putusan No: 09/BPSK-SBY/Put-Arbitrase/II/2019 yang 
dilakukan Majelis BPSK Surabaya, bahwasannya gugatan CW dikabulkan dan pelaku usaha wajib mengembalikan Rp. 451.500 .000 serta mengganti 1 (satu) unit sejenis tipe Praha atau setara nilainya selambat-lambatnya 14 hari terhitung setelah putusan tersebut diterima oleh Tergugat. Namun sampai sekarang belum ada itikad baik Tergugat untuk menyelesaikan permasalahan ini.

Sama halnya dengan kasus diatas, 8 (delapan) konsumen lainnya juga merasa dirugikan oleh PT. Berkata Jaya Land mengajukan gugatannya ke Pengadilan Negeri Gresik atas gugatan wanprestasi antara lain:

Para pihak ini melakukan aksi Class Action, karena memiliki permasalahan yang sama yaitu Tergugat tidak memenuhi kewajibannya (wanprestasi) antara lain: 1. Bahwa para pihak belum memperoleh tanah dan bangunan rumah:

a. Type Praha A5 No 26 Luas Tanah/ Bangunan 54/90 Seharga Rp. 240.000.000,atas nama IY;

b. Type Crystaline A12 No 19 Luas Tanah dan Bangunan 36/70 sebesar Rp. 263.250.200,- atas nama IA;

c. Type PrahaA5 No 8 Luas Tanah dan Bangunan 54/90 sebesar Rp 340.000.000,atas nama EK;

d. Type Praha A5 No 24 Luas Tanah dan Bangunan 54/90 sebesar Rp 240.000.000,- atas nama WI;

e. Crystaline A11 No 15 Luas Tanah dan Bangunan 36/70 sebesar Rp. 285.102.400,- atas nama LN;

f. Type Praha A5 No 28 Luas Tanah dan Bangunan 54/90 sebesar Rp. 240.000.000,- atas nama HY;

g. Type CapilandA11 No 3 Luas Tanah dan Bangunan 45/80 Sebesar Rp. 209.542.613,- atas nama HY (RELOKASI);

h. Type Capiland A12 No 3A Luas Tanah dan Bangunan 45/81 Sebesar Rp. 290.750.000,- atas nama GS;

i. Type Praha A5 No 22 Luas Tanah dan Bangunan 54/90 Sebesar Rp. 434.700.000,- atas nama AS.

2. Bahwa para pihak belum mendapatkan bukti lunas atas pembelian tanah dan bangunan/perumahan

3. Bahwa para pihak belum mendapatkan Akta Jual Beli (AJB) atas pembelian tanah dan bangunan/perumahan

Sidang yang dilakukan dari tanggal 30 April 2019 hingga 16 Agustus 2019, memutus perkaranya dengan cara kesepekatan perdamaian bahwa: 
1. Pihak pertama (penggugat) berhak mendapatkan tanah beserta bangunan diatasnya dan dapat dikuasai olehnya;

2. Pihak pertama berhak atas bukti pelunasan;

3. Pihak pertama berhak mendapatkan Akta Jual Beli (AJB) atas pembelian dan bangunan/perumahan;

4. Pihak pertama wajib menyerahkan bukti pelunasan kepada pihak kedua (tergugat);

5. Para pihak sepakat bahwa Kesepakatan Perdamaian ini sebagai salah satu syarat untuk pembuatan Akta Jual Beli (AJB) terhadap pembelian tanah dan bangunan rumah pada Perumahan Royal City;

6. Kesepakatan Perdamaian ini sebagai kuasa kepada Pihak Pertama untuk pembuatan Akta Jual Beli (AJB) kepada Pejabat Pembuat Akta Tanah (PPAT) Wilayah Gresik terhadap pembelian tanah dan bangunan rumah pada Perumahan Royal City;

7. Menyatakan putusan dalam perkara ini dapat dijalankan terlebih dahulu/ serta merta/ uitvoerbaar bij vooraad walaupun ada verzet, banding, dan kasasi;

8. Menghukum kepada Tergugat untuk membayar seluruh biaya perkara ini.

Berdasarkan kedua perkara diatas maka penting setiap perbuatan hukum perlu memiliki suatu hubungan hukum untuk memberikan hak dan kewajiban yang diatur dalam aturan hukum sehingga apabila orang-orang melanggar maka dapat dituntut di muka pengadilan. Menurut teori hukum, perbuatan yang merugikan tersebut dapat lahir karena: ${ }^{6}$

1. Tidak ditepatinya suatu perjanjian atau kesepakatan yang telah dibuat (yang pada umumnya dikenal dengan istilah wan-prestasi); atau

2. Semata-mata lahir karena suatu perbuatan tersebut (atau yang dikenal dengan perbuatan melawan hukum).

Sesuai teori di atas maka akibat dari Perjanjian Pengikatan Jual Beli yang para pihak buat merupakan perbuatan yang merugikan para pihak karena salah satu pihak tidak melaksanakan kewajiban yang telah dituang dalam perjanjian tersebut. Perbuatan merugikan tersebut disebut wanprestasi. Seseorang yang dianggap wanprestasi dalam suatu perjanjian menurut Pasal 1238 BW ialah "Debitur dinyatakan Ialai dengan surat perintah, atau dengan akta sejenis itu, atau berdasarkan kekuatan dari perikatan sendiri, yaitu bila perikatan ini mengakibatkan debitur harus dianggap Ialai dengan lewatnya waktu yang ditentukan”.

6 ibid.[62]. 
Menurut Subekti, bentuk wanprestasi dibedakan menjadi: ${ }^{7}$

1. Tidak memenuhi prestasi sama sekali (non performance);

2. Terlambat memenuhi prestasi (delay/late of performance);

3. Memenuhi prestasi tidak sebagaimana diperjanjikan (perform defectively);

4. Melakukan sesuatu yang seharusnya tidak dilaksanakan (perform something which is prohibited).

Kaitannya dengan kedua perkara tersebut merupakan bentuk wanprestasi dimana pelaku usaha tidak memenuhi prestasinya sama sekali (non performance). Tergugat yang seharusnya melaksanakan kewajibannya dengan menyerahkan rumah kepada Penggugat pada tenggang waktu seperti yang telah disepakati dalam perjanjian namun sampai sekarang Penggugat belum memperoleh hak nya tersebut padahal ia telah melaksanakan kewajibannya sebagai konsumen dengan membayar lunas objek perikatan berupa rumah tersebut.

Dunia perdagangan yang berevolusi dari waktu ke waktu menyebabkan produk barang dan jasa yang hendak digunakan konsumen untuk menunjang kebutuhan hidupnya semakin lama semakin cangih sehingga timbul kesenjangan terhadap kebenaran informasi yang diperoleh dan perbedaan daya tanggap tiap konsumen. Keadaan seperti ini secara tidak langsung memberikan dampak yang menguntungkan sekaligus merugikan bagi konsumen.

Kondisi seperti ini menunjukkan bahwa adanya kelemahan pada konsumen menyebabkan pelaku usaha berusaha meraup keuntungan dari kelemahan tersebut sehingga kedudukan konsumen menjadi tidak aman. Sudah menjadi kenyataan bahwa kedudukan pelaku usaha memiliki posisi yang lebih unggul daripada konsumen, baik dari aspek ekonomi, pengetahuan, maupun kemampuan. ${ }^{8} \mathrm{Kelemahan}$ konsumen tersebut membuat pelaku usaha menjadikannya sebagai obyek daripada subyek padahal seharusnya konsumen dijadikan subyek hukum yang dapat dijadikan sebagai partner untuk berkerja sama.

Prinsip saling menguntungkan satu sama lain haruslah diutamakan bahwa dalam suatu hubungan kepentingan bersama harus dikedepankan dengan kata lain

\footnotetext{
7 Leonora Bakarbessy, [et al], Buku ajar Hukum Perikatan (Universitas Airlangga 2010).[19].

8 Sri Handajani, Buku ajar Hukum Perlindungan Konsumen (Universitas Airlangga 2006).[2].
} 
kepentingan pribadi tidak selalu harus didahulukan. Namun kecenderungan pelaku usaha dalam memanfaatkan kedudukan konsumen menjadi fenomenal sehingga membuka kesadaran konsumen untuk mendapatkan perlindungan di mata hukum.

Hukum berfungsi sebagai perlindungan kepentingan manusia agar setiap perbuatan yang dilakukan manusia dapat terlindungi oleh hukum dengan kata lain hukum dibuat untuk manusia dan dilaksanakan oleh manusia juga hal tersebut lah yang menyebabkan pentingnya kepentingan manusia untuk dilindungi. Hukum pribadi merupakan hukum yang mengatur hak-hak dan kewajiban-kewajiban pribadi sebagai "subjek hukum" disebut Hukum Pribadi, bila dikaitkan dengan alasan pentingnya kedudukan konsumen untuk dilindungi hal itu disebabkan karena bila dalam suatu perbuatan hukum ada hak-hak dan kewajiban-kewajiban subjek hukum yang dilanggar maka dapat dilakukan penegakan hukum yang mencakup 3 (tiga) unsur antara lain: ${ }^{9}$

1. Kepastian Hukum, merupakan perlindungan yustisiabel terhadap tindakan sewenang-wenang yang berarti bahwa seseorang akan dapat memperoleh sesuatu yang diharapkan dalam keadaan tertentu. Tujuan diadakannya kepastian hukum agar terciptanya ketertiban masyarakat;

2. Kemanfaatan, hukum adalah untuk manusia maka penegakan hukum harus memberikan manfaat serta kegunaan bagi masyarakat;

3. Keadilan, dalam penegakan hukum harus menegakkan keadilan tanpa memerhatikan subyek tertentu dan tidak menyamaratakan.

Ada beberapa alasan mengapa konsumen perlu mendapatkan perlindungan yang layak oleh negara antara lain: ${ }^{10}$

a. Perlindungan konsumen merupakan upaya yang mencerminkan perlindungan terhadap seluruh elemen bangsa Indonesia yang merupakan amanat dari pembangunan nasional;

b. Perlindungan konsumen dimaksudkan untuk menghindarkan konsumen dari dampak negatif penggunaan teknologi;

c. Perlindungan konsumen bertujuan untuk melahirkan individu-individu yang sehat jasmani dan rohani sebagai pelaku pembangunan ekonomi sosial;

9 Sudikno Mertokusumo, Mengenal Hukum: Suatu Pengantar (Liberty 2005).[160-161]

${ }_{10}$ M. Natsir Asnawi, Aspek Hukum Janji Prakontrak (UII Press 2017).[134]. 
d. Perlindungan konsumen perlu untuk menjamin ketersediaan dan penggunaan sumber dana pembangunan yang berasal dari masyarakat konsumen untuk kepentingan konsumen pada khususnya dan bangsa Indonesia pada umumnya.

Pembentukan Undang-Undang Perlindungan Konsumen pada dasarnya untuk memberikan kesetaraan kedudukan antara konsumen dan pelaku usaha sebagaimana bunyi dalal Pasal 27 ayat (1) Undang-Undang Dasar 1945, "Segala warga negara bersamaan kedudukannya di dalam hukum dan pemerintahan dan wajib menjunjung hukum dan pemerintahan itu dengan tidak ada kecualinya."

Di Indonesia masalah perlindungan konsumen mulai terdengar pada tahun 1970-an yang ditandai dengan lahirnya Yayasan Lembaga Konsumen (YLK) bulan Mei 1973. Faktor utama yang menjadi kelemahan konsumen adalah tingkat kesadaran konsumen bahwa haknya masih rendah. ${ }^{11}$ Atas dasar desakan tersebut, masyarakat menyuarakan dirinya untuk dilindungi sehingga lahirlah UndangUndang Nomor 8 Tahun 1999 tentang Perlindungan Konsumen. Alasan yang dapat dikemukakan terkait penerbitan peraturan perundang-undangan yang secara khusus mengatur dan melindungi kepentingan konsumen karena konsumen memerlukan pengaturan sendiri agar dalam suatu hubungan hukum dengan penjual, konsumen dapat menggunakan barang dan jasa hanya untuk kepentingan sendiri dan tidak untuk diproduksi ataupun diperdagangkan serta konsumen memerlukan sarana sebagai upaya untuk melindungi dan memperoleh haknya.

Perlindungan konsumen pada Pasal 1 ayat (1) Undang-Undang Nomor 8 Tahun 1999 tentang Perlindungan Konsumen merupakan "upaya yang menjamin adanya kepastian hukum untuk memberi perlindungan kepada konsumen.” Peranti hukum yang disebutkan dalam Undang-Undang Perlindungan Konsumen tidak dimaksutkan untuk mematikan usaha para pelaku usaha, sebaliknya sebab perlindungan konsumen dapat mendorong iklim berusaha yang sehat serta lahirnya perusahaan yang tangguh dalam menghadapi persaingan melalu penyediaan barang dan/atau jasa yang berkualitas.

\footnotetext{
${ }^{11}$ Adrian Sutedi, Tanggung Jawab Produk dalam Hukum Perlindungan Konsumen (Ghalia Indonesia 2008).[1].
} 
Pasal 2 Undang-Undang Nomor 8 Tahun 1999 tentang Perlindungan Konsumen disebutkan perlindungan konsumen berasaskan manfaat, keadilan, keseimbangan, keamanan dan keselamatan, serta kepastian hukum. Mencermati asas diatas, Ahmad miru mengemukakan pendapat yaitu: ${ }^{12}$

1. Asas kemanfaatan yang di dalamnya meliputi asas kemanfaatan dan keselamatan konsumen;

2. Asas keadilan yang didalamnya meliputi asa keseimbangan;

3. Kepastian hukum.

Adapun dalam Pasal 3 Undang-Undang Nomor 8 Tahun 1999 tentang

Perlindungan Konsumen disebutkan tujuan perlindungan hukun, antara lain:

a. Menjaga kepentingan umum dan meningkatkan efisiensi ekonomi nasional sebagai salah satu upaya untuk meningkatkan kesejahteraan rakyat;

b. Mewujudkan iklim usaha yang kondusif melalui pengaturan persaingan usaha yang sehat sehingga menjamin adanya kepastian kesempatan berusaha yang sama bagi pelaku usaha besar, pelaku usaha menengah, dan pelaku usaha kecil;

c. Mencegah praktek monopoli dan atau persaingan usaha tidak sehat yang ditimbulkan oleh pelaku usaha; dan

d. Terciptanya efektivitas dan efisiensi dalam kegiatan usaha.

Dalam Undang-Undang Nomor 8 Tahun 1999 tentang Perlindungan

Konsumen diatur mengenai hak konsumen pada Pasal 4 sebagai berikut:

a. hak atas kenyamanan, kemanan, dan keselamatan dalam mengkonsumsi barang dan/atau jasa;

b. hak untuk memilih barang dan/atau jasa, serta mendapatkan barang dan/atau jasa tersebut sesuai dengan nilai tukar dan kondisi, serta jaminan yang dijanjikan;

c. hak atas informasi yang benar, jelas, dan jujur mengenai kondisi dan jaminan barang dan/atau jasa;

d. hak untuk didengar pendapat dan keluhannya atas barang dan/atau jasa yang digunakan;

e. hak untuk mendapatkan advokasi, perlindungan, dan upaya penyelesaian sengketa perlindungan konsumen secara patut;

f. hak untuk mendapat pembinaan dan pendidikan kosnumen;

g. hak untuk diperlakukan atau dilayani secara benar, jujur, serta tidak diskriminatif;

h. hak untuk mendapatkan kompensasi, ganti rugi dan/atau penggantian, apabila barang dan/atau jasa yang diterima tidak sesuai dengan perjanjian atau tidak sebagaimana mestinya;

${ }^{12}$ Sri Handajani, [et al], Op.Cit.[10]. 
i. hak-hak yang diatur dalam ketentuan peraturan perundang-undangan laiannya.

Ketentuan Undang-Undang Nomor 8 Tahun 1999 tentang Perlindungan Konsumen ini bila dikaitkan dengan Putusan No: 09/BPSK-SBY/Put-Arbitrase/ II/2019 dan Putusan No. 33/Pdt.G/2019/PN Gresik, pokok perkara kedua kasus tersebut tidak dikenal dengan sebutan wanprestasi melainkan perbuatan melanggar hukum hal ini dikarenakan wanprestasi mensyaratkan adanya hubungan kontraktual dimana pembayaran ganti rugi berdasarkan penerapan klausula dalam perjanjian yang dibuat sehingga dalam Undang-Undang Perlindungan Konsumen tidak diatur tuntutan tanggung jawab atas wanprestasi.

Tuntutan ganti rugi didasarkan pada perbuatan melanggar hukum karena tidak perlu didahului perjanjian atau adanya hubungan kontraktual antara pelaku usaha dan konsumen sehingga tuntutan ganti rugi dapat dilakukan oleh setiap pihak yang dirugikan walaupun tidak terdapat perjanjian antara pelaku usaha dan konsumen. Beban pembuktian atas kesalahan pelaku usaha diatur dalam Pasal 22 dan Pasal 28 Undang-Undang Nomor 8 Tahun 1999 tentang Perlindungan Konsumen bahwasannya kewajiban pembuktian dibebankan dan merupakan kewajiban dari pelaku usaha sepenuhnya. ${ }^{13}$

Berdasarkan Pasal 1365 BW yang berbunyi “Tiap perbuatan yang melanggar hukum dan membawa kerugian kepada orang lain, mewajibkan orang yang menimbulkan kerugian itu karena kesalahannya untuk menggantikan kerugian tersebut." maka pihak yang dirugikan dapat menuntut haknya apabila telah memenuhi unsur-unsur:

1. Ada perbuatan melanggar hukum, menurut Van Der Grinten melanggar hak orang lain yang menimbulkan kerugian karena kesalahan dari orang yang bersangkutan dikategorikan sebagai perbuatan melanggar hukum. ${ }^{14}$

2. Ada kerugian, kerugian yang diderita seseorang dibagi menjadi 2 (dua) bagian yaitu kerugian yang menimpa diri dan kerugian yang menimpa harta benda seseorang dan kerugian harta benda sendiri yaitu kerugian nyata yang dialami

\footnotetext{
${ }^{13}$ Gunawan Widjaja dan Ahmad Yani, Op.Cit.[69].

${ }^{14}$ Ahmadi Miru dan Sutarman Yodo, Hukum Perlindungan Konsumen (RajaGrafindo Persada 2004).[131].
} 
serta kehilangan keuntungan yang diharapkan. ${ }^{15}$

3. Ada hubungan kausalitas antara perbuatan melanggar hukum dan kerugian, menurut Ps. 1365 BW baru menentukan bahwa "kerugian hanya dapat dipertimbangkan untuk diganti ialah yang ada hubungan sedemikian rupa dengan kejadian dasar pertanggunggugatan orang yang bersalah, sehingga kerugian ini, sebagai akibat dari kejadian itu dapat dipertanggungkan kepadanya dengan mempertimbangkan juga sifat pertanggunggugatan dan sifat kerugian." artinya kerugian yang dapat diganti apabila kejadian yang menyebabkan kerugian tersebut akibat orang yang bersalah. Jadi ada hubungan antara kerugian yang dialami dengan kejadian disebabkan orang yang bersalah.

4. Ada kesalahan, ada tiga unsur yang dapat mengatakan terjadinya kesalahan:
a. Perbuatan yang dilakukan dapat disesalkan;
b. Perbuatan tersebut dapat diduga akibatnya;
c. Dapat dipertanggungjawabkan debitur (cakap).

Maka tuntutan ganti rugi perbuatan melanggar hukum yang dapat dilakukan seorang konsumen apabila:

1. Negligence, artinya kelalaian atau kurang kehatian-hatian atau kurang cermat ini terjadi apabila suatu perilaku tidak sesuai dengan standar kelakukan yang ditetapkan dalam undang-undang demi perlindungan anggota masyarakat terhadap unreasonable risk. ${ }^{16}$ Ada beberapa unsur dasar gugatan berdasarkan negligence antara lain: ${ }^{17}$

a. Suatu tingkah laku yang menimbulkan kerugian, tidak sesuai dengan sikap hati-hati yang normal;

b. Yang harus dibuktikan ialah bahwa tergugat lalai dalam kewajiban berhatihatinya terhadap penggugat;

c. Kelakuan itu merupakan penyebab yang nyata (proximate cause) dari kerugian yang timbul.

2. Breach of implied warranty, pelanggaran janji/jaminan tersebut. Gugatan ini dapat diterima walaupun tanpa hubungan kontrak dengan praktek perdagangan yang modern. ${ }^{18}$

3. Breach of an express warranty, cukup dengan adanya keterangan, janji, atau

\footnotetext{
15 ibid.[133].

16 ibid.[147].

17 ibid.

18 ibid.[148].
} 
gambaran yang diberikan penjual dan merupakan bagian dari perjanjian. ${ }^{19}$

Tanggung Jawab Pelaku Usaha diatur dalam Pasal 19 Undang-Undang Nomor 8 Tahun 1999 tentang Perlindungan Konsumen yang dapat diberikan sebagai bentuk ganti rugi diantaranya:

(1) Pelaku usaha bertanggung jawab memberikan ganti rugi atas kerusakan, pencemaran, dan/atau kerugian konsumen akibat mengkonsumsi barang dan/atau jasa yang dihasilkan atau diperdagangkan.

(2) Ganti rugi sebagaimana dimaksud pada ayat (1) dapat berupa pengembalian uang atau penggantian barang dan/atau jasa yang sejenis atau setara nilainya, atau perawatan kesehatan dan/atau pemberian santunan yang sesuai dengan ketentuan peraturan perundang-undangan yang berlaku.

(3) Pemberian ganti rugi dilaksanakan dalam tenggang waktu 7 (tujuh) hari setelah tanggal transaksi.

(4) Pemberian ganti rugi sebagaimana dimaksud pada ayat (1) dan ayat

(2) tidak menghapuskan kemungkinan adanya tuntutan pidana berdasarkan pembuktian lebih lanjut mengenai adanya unsur kesalahan.

(5) Ketentuan sebagaimana dimaksud pada ayat (1) dan ayat (2) tidak berlaku apabila pelaku usaha dapat membuktikan bahwa kesalahan tersebut merupakan kesalahan konsumen.

\section{Upaya Hukum atas Penyeleseaian Sengketa Jual Beli Rumah dengan Mekanisme Perjanjian Pengikatan Jual Beli}

Class action adalah suatu tata cara pengajuan gugatan, dalam mana satu orang atau lebih yang mewakili kelompok mengajukan gugatan untuk diri atau diri-diri mereka sendiri dan sekaligus mewakili sekelompok orang yang jumlahnya banyak, yang memiliki kesamaan fakta atau dasar hukum antara wakil kelompok dan anggota kelompok dimaksud.

Dalam melakukan class action ada beberapa keuntungan dan kelemahan diantaranya:

1. Proses berpekara menjadi sangat ekonomis;

2. Akses lebih mudah untuk memperoleh keadilan;

3. Mendorong sikap kehati-hatian dan mengubah sikap pelaku pelanggaran.

Selain kelebihan ada juga kelemahan diantaranya:

1. Kesulitan mengelola jumlah kelompok yang berjumlah banyak.

19 ibid.[149]. 
2. Menyebabkan ketidakadilan.

3. Menyebabkan kebangkrutan pada tergugat.

4. Publikasi gugatan class action menyudutkan tergugat.

Tata cara dan persyaratan gugatan perwakilan kelompok dijelaskan secara rindi dalam BAB II Peraturan Mahkamah Agung No. 1 Tahun 2002 tentang Acara Gugatan Perwakilan Kelompok.

Tahapan akhir setelah adanya putusan yang berkekuatan hukum tetap adalah pelaksanaan putusan (eksekusi) yaitu:

1. Eksekusi putusan yang menghukum pihak yang kalah untuk membayar sejumlah uang. (Pasal 96 HIR atau 208 Rgb);

2. Eksekusi putusan yang menghukum orang untuk melakukan suatu perbuatan. (Pasal 225 HIR atau Pasal 259 Rgb);

3. Eksekusi riil yaitu pelaksanaan prestasi yang dibebankan debitur oleh putusan hakim secara langsung. (Pasal 1033 Rv).

Beban pembuktian tetap ada pada pihak yang merugikan (pelaku usaha) dengan keharusan untuk membuktikan beberapa hal antara lain:

1. Konsumen secara actual telah mengalami kerugian;

2. Konsumen membuktikan kerugian yang terjadi akibat dari penggunaan, pemanfaatan, atau pemakaian barang dan/atau jasa tersebut merupakan tanggung jawab dari pelaku usaha tertentu;

3. Tidak kelayakan dari penggunaan, pemanfaatan, atau pemakaian barang dan/ atau jasa merupakan tanggung jawab dari pelaku usaha;

4. Konsumen tidak berkontribusi, baik secara langsung atau tidak langsung atas kerugian yang diderita.

Bila teori diatas dikaitkan dengan perkara Putusan No. 33/Pdt.G/2019/PN Gresik Putusan No. 33/Pdt.G/2019/PN Gresik maka Class Action yang dilakukan para Penggugat adalah benar karena para Penggugat memiliki kepentingan dan fakta hukum yang sama yakni mengalami kerugian akibat perjanjian jual beli yang dilakukan dengan PT. Berkat Jaya Land. Pada dasarnya apabila terjadi sengketa antara kedua belah pihak lebih baik diselesaikan secara musyawarah terlebih dahulu namun bila menemukan titik tengah maka pihak yang merasa dirugikan berhak menuntut hak nya melalui lembaga pengadilan. 
Gugatan yang dilakukan para Penggugat untuk menyelesaikan sengketa dengan PT. Berkat Jaya Land ke Pengadilan Negeri Gresik berakhir dengan perdamaian melalui mediasi. Dalam gugatan Class Action memang dimungkinkan terjadi perdamaian maka dari itu Hakim berkewajiban untuk mendorong para pihak dalam menyelesaikan perkara tersebut melalui perdamaian, baik pada awal persidangan maupun selama berlangsungnya pemeriksaan perkara, sebagaimana ditentukan dalam Pasal 6 PERMA No. 1 Tahun 2002 tentang Acara Gugatan Perwakilan Kelompok. Perjanjian perdamaian dibuat dalam bentuk akta atau secara tertulis. Berdasarkan perjanjian perdamaian antara kedua belah pihak maka hakim menjatuhkan putusannya (acte van verjelijk) yang isinya menghukum kedua belah pihak mematuhi isi perdamaian yang telah dibuat.

Selain itu, Undang-Undang Perlindungan Konsumen memberikan alternatif lain dalam menyelesaikan sengketa melalui lembaga pengadilan penyelesaian sengketa melalui pembicaraan antara para pihak dan melalui lembaga yang khusus dibentuk oleh undang-undang yakni Badan Penyelesaian Sengketa Konsumen (BPSK). BPSK adalah Badan yang bertugas menangani dan menyelesaikan sengketa antara pelaku usaha dengan konsumen.

Penyelesaian sengketa melalui BPSK dapat dilakukan dengan 3 (tiga) cara diantaranya:

1. Konsoliasi

Konsoliasi adalah Proses penyelesaian sengketa konsumen di luar pengadilan dengan perantaraan BPSK untuk mempertemukan para pihak yang bersengketa, dan penyelesaiannya diserahkan kepada para pihak. Cara ini ditempuh atas inisiatif salah satu pihak atau keduanya. Majelis BPSK bertindak sebagai konsiliator pasif yang artinya proses penyelesaian sengketa diberikan sepenuhnya kepada konsumen dan pelaku usaha yang bersangkutan mengenai bentuk maupun jumlah ganti rugi.

2. Mediasi

Mediasi adalah proses penyelesaian sengketa konsumen di luar pengadilan denganperantaraan BPSK sebagai penasehat dan penyelesaiannya diserahkan 
kepada para pihak. Sama halnya dengan konsoliasai perbedaannya majelis BPSK bersifat aktif untuk mendamaikan para pihak serta memberi saran atas penyelesaian sengketa sesuai dengan UUPK.

\section{Arbitrase}

Arbitrase adalah proses penyelesaian sengketa konsumen di luar pengadilan yang dalamhal ini para pihak yang bersengketa menyerahkan sepenuhnya penyelesaian sengketa kepada BPSK artinya para pihak menyerahkan sepenuhnya kepada majelis BPSK untuk memutus dan menyelesaikan sengketa konsumen yang terjadi. Para pihak memilih arbiter dari anggota BPSK yang berasal dari unsur pelaku usaha dan konsumen sebagai anggota majelis. Setelah itu arbitor yang terpilih memilih arbitor ketiga dari anggota BPSK yang berasal dari unsur pemerintah sebagai Ketua Majelis.

Putusan BPSK bersifat final dan mengikat walau begitu Pasal 56 ayat (6) jo. Pasal 58 Undang-Undang Nomor 8 Tahun 1999 tentang Perlindungan Konsumen para pihak memungkinkan untuk mengajukan keberatan ke Pengadilan Negeri dan kasasi ke Mahkamah Agung.

Gugatan yang telah dikabulkan maka pelaku usaha berkewajiban:

1. Ganti rugi atas kerugian atas kerusakan, pencemaran dan/atau kerugian konsumen akibat mengkonsumsi barang dan/atau memanfaatkan jasa yang dapat berupa:

a. Pengembalian uang;

b. Penggantian barang dan/atau jasa yang sejenis atau setara nilainya;

c. Perawatan kesehatan dan/atau pemberian santunan (Pasal 19 ayat (1) dan (2) Undang-Undang Nomor 8 Tahun 1999 tentang Perlindungan Konsumen serta Pasal 12 SK Menperindag No. 350/MPP/Kep/12/2001.

2. Sanksi administratif berupa penetapan ganti rugi maksimal Rp. 200.000.000,-

Berdasarkan teori diatas bila dikaitkan dengan perkara Putusan No: 09/BPSKSBY/Put-Arbitrase/II/2019 bahwa upaya hukum dengan menyelesaikan sengketa dengan cara Arbitrase yang dilakukan Christian Wijaya (Penggugat) adalah benar. Penyelesaian sengketa yang dilakukan secara arbitrase dikarenakan ketidakhadiran Tergugat pada sidang sebanyak 3 kali serta tidak diaturnya penyelesaian bila terjadi 
sengketa dalam Perjanjian Pengikatan Jual Beli yang dibuat oleh para pihak.

Hal ini dikarenakan Tergugat terbukti tidak melaksanakan kewajibannya yaitu membangun rumah Type Praha di perumahan Royal City sebagaimana yang telah diperjanjikan dan dituangkan dalam Perjanjian Pengikatan Jual Beli yang Christian Wijaya dan PT. Berkat Jaya Land padahal Christian Wijaya telah melaksanakan kewajibannya dengan membayar penuh objek perikatan tersebut. Berdasarkan alat bukti yang telah diserahkan dan kemudian dipertimbangkan oleh Majelis BPSK maka gugatan Christian Wijaya dikabulkan seluruhnya.

BPSK menyatakan bahwasannya PT. Berkat Jaya Land dinyatakan bersalah dan harus mengganti kerugian yang dialami oleh Christian Wijaya antara lain:

1. Bahwa Tenggugat wajib mengembalikan uang senilai Rp. 451.000.000,selambat-lambatnya 14 hari kerja terhitung sejak tanggal putusan ini diterima oleh Tergugat;

2. Bahwa Tergugat mengganti rumah 1 (satu) unit rumah yang sejenis dengan Type Praha yang ada di perumahan Royal City, Gresik.

3. Menghukum sanksi administrasi kepada Tergugat sebagaimana diatur dalam Undang-Undang Nomor 8 Tahun 1999 tentang Perlindungan Konsumen Pasal 60 ayat (1) karena Tergugat secara meyakinkan telah melanggar Pasal 26 UndangUndang Nomor 8 Tahun 1999 tentang Perlindungan Konsumen.

4. Menghukum sanksi pidana kepada Tergugat karena Tergugat secara meyakinkan telah melanggar Pasal 16 Undang-Undang Nomor 8 Tahun 1999 tentang Perlindungan Konsumen.

\section{Kesimpulan}

Perlindungan hukum merupakan tpemenuhan hak-hak para pihak apabila salah satu pihak melakukan wanprestasi atau ingkar janji. Sejatinya dalam perjanjian pengikatan jual beli sangat tergantung kepada kekuatan dari Perjanjian Pengikatan Jual beli yang dibuat, yaitu jika dibuat dengan Akta di bawah tangan maka perlindungannya tunduk pada ketentuan Akta dibawah tangan, sedangkan bila di buat oleh atau di hadapan Pejabat Pembuat Akta maka Akta tersebut tunduk pada kekuatan sesuai dengan perlindungan terhadap Akta Otentik.

Upaya hukum yang dapat dilakukan konsumen dalam melakukan penyelesaian sengketa dapat melalui luar pengadilan (BPSK) dengan menggunakan instrumen Pasal 16 dan Pasal 18 Undang-Undang No. 8 Tahun 1999 tentang Perlindungan 
Konsumen serta penyelesaian sengketa melalui pengadilan yaitu penyelesaian secara perdata dengan menggunakan instrumen Pasal 1267 BW (gugatan wanprestasi) dan Pasal 1365 BW (gugatan perbuatan melawan hukum) serta penyelesaian secara pidana berdasarkan ketentuan pidana pada Pasal 151 Undang-Undang Nomor 1 Tahun 2011 tentang Perumahan dan Pemukiman.

\section{Daftar Bacaan}

\section{Buku}

Urip Santoso, Hukum Perumahan (Kencana 2016).

Celina Tri Siwi Kristiyanti, Hukum Perlindungan Konsumen (Sinar Grafika 2018).

Gunawan Widjaja dan Ahmad Yani, Hukum tentang Perlindungan Konsumen (Gramedia Pustaka Utama 2000).

Leonora Bakarbessy et al., Buku ajar Hukum Perikatan (Universitas Airlangga 2010).

Sri Handajani, Gianto Al Imron dan Bambang Sugeng Ariadi, Buku ajar Hukum Perlindungan Konsumen (Universitas Airlangga 2006).

Sudikno Mertokusumo, Mengenal Hukum: Suatu Pengantar (Liberty 2005).

Natsir Asnawi, Aspek Hukum Janji Prakontrak (UII Press 2017).

Adrian Sutedi, Tanggung Jawab Produk dalam Hukum Perlindungan Konsumen (Ghalia Indonesia 2008).

Ahmadi Miru dan Sutarman Yodo, Hukum Perlindungan Konsumen (RajaGrafindo Persada 2004). 
1750 Febriyanti Putri: Perlindungan Hukum Bagi

--halaman ini sengaja dibiarkan kosong-- 